\title{
Mind Mapping and Philosophy in Junior High School: A Comparative Study of Initial Philosophical Writing in Classes of 8th Grade Pupils Used and Unused to Philosophically Directed Discussion
}

\author{
Emmanuèle Auriac-Slusarczyk ${ }^{1}$, Bernard Slusarczyk ${ }^{1,2}$, Cathy Thebaultt,3 \\ ${ }^{1}$ Laboratoire ACTé, Université Clermont Auvergne, Clermont-Ferrand, France \\ ${ }^{2}$ Collège, A.G. Monnet, Champeix, France \\ ${ }^{3}$ Self-Employed Trainer, Montaigut, L'Isle-sur-Tarn, France \\ Email: emmanuele.auriac@uca.fr
}

How to cite this paper: Auriac-Slusarczyk, E., Slusarczyk, B., \& Thebault, C. (2018). Mind Mapping and Philosophy in Junior High School: A Comparative Study of Initial Philosophical Writing in Classes of 8th Grade Pupils Used and Unused to Philosophically Directed Discussion. Creative Education, 9, 1312-1331.

https://doi.org/10.4236/ce.2018.99098

Received: March 21, 2018

Accepted: July 9, 2018

Published: July 12, 2018

Copyright $\odot 2018$ by authors and Scientific Research Publishing Inc. This work is licensed under the Creative Commons Attribution International License (CC BY 4.0).

http://creativecommons.org/licenses/by/4.0/

\section{(c) (i) Open Access}

\begin{abstract}
This study compares the written production of 8th grade junior high school pupils in two conditions. Four experimental classes used to philosophically directed discussion (PDD) in the classroom were asked, as part of a teaching program (Philo \& Carto), to implicitly link pictorial items in selected cultural heritage artworks (Brueghel, Niki de St Phalle, Magritte, etc.) to their ideas discussed collectively in philosophical discussions. The pupils in three control classes, with no prior experience of philosophical discussions, were shown the same artworks and asked for their impressions in art classes. We compared how philosophy entered written communication in the two conditions. By sorting the types of rough notes (outlines of ideas) produced by the pupils into seven categories using an inductive approach, we found that the PDD classes produced more conceptual and better organized rough notes than the controls, that distanced themselves less from the artwork and so produced conceptually poorer notes. These findings argue for formalizing the theoretical and practical basis of the Philo \& Carto teaching program. Our conclusion discusses the limitations of the study and suggests some further research directions.
\end{abstract}

\section{Keywords}

Childhood, Philosophical Dialogue, Writing at School, Creativity, Mapping, Teaching Program 


\section{Introduction}

The experiment described here was conducted as part of an action-research program hosted by the recently created Instituts Carnot d'Éducation (ICE) (Auriac-Slusarczyk, Slusarczyk, \& Thebault, 2016; Fougères, 2016). An ICE ${ }^{1}$ is "a structure for exchange, dialogue and the construction of joint projects bringing together schools and academia, for the benefit of pupils, centered on teaching practices, and prompted by issues raised by teaching staff in schools." ${ }^{2}$ The research project originated from a formal request by 7 th grade junior school pupils, who after two years of philosophical discussion classes in their school were taught by teachers of French, history and geography using a well-proven protocol (cf. Auriac-Slusarczyk, Slusarczyk, \& Charles-Beaucourt, 2011; Fiema, 2015). The pupils wanted: 1) to continue the collective philosophically directed discussions, and 2) to start philosophical writing, noting down their ideas themselves, an action hitherto restricted to their teacher. Meanwhile, in France, official education guidelines have instituted these philosophically directed activities, termed DVP for discussion à visée philosophique, as models of practices encouraged for ethics and civic education and as part of developing citizenship (M.E.N., 2015a, 2015b, 2015c). The English equivalent philosophically directed discussion (PDD) will be used in what follows. The purpose of our experiment was to determine whether setting in place the writing activity requested by the pupils was beneficial to them, and whether it might divert from the aims of PDD, which in usual practice is conducted only orally.

\section{Theoretical Framework}

The practice of collective philosophically directed discussion as pioneered by Matthew Lipman, initially presented by Lipman and coworkers (Lipman, Oscanyan, \& Sharp, 1980), was spread by Lipman himself during his lifetime (Lipman, 1995), and by his followers (Daniel, 1992/1997, 2008). Now in use worldwide (for a recent review see Gregory, Hayes, \& Murris, 2017), it has been studied in several complementary ways from a teaching perspective (Auriac-Slusarczyk \& Maufrais, 2010) through multidisciplinary contributions (Saint-Dizier de Almeida \& Auriac-Slusarczyk, 2016), and remains a subject of debate and indeed controversy (Leleux, 2005). It is of proven benefit in several domains (e.g. Millett \& Tapper, 2012; Topping \& Trickey, 2007) including reasoning, motivation, socialization, and self-esteem, when associated with oral practice (see Tozzi, 2007, for example).

PDD at junior high school has also been the subject of several studies in France that have confirmed its utility and soundness (Auriac-Slusarczyk, Slusarczyk, \& Charles-Beaucourt, 2011; Fiema, 2015). Pioneering studies conducted in primary school classes had already shown, from a study of argumentative ${ }^{1}$ The present I.C.E. is an experimental structure set up in the Auvergne-Rhône-Alpes (AURA) Region, France, that combines educational action (local schools authority) and academic research. ${ }^{2}$ Quoted from the agreement signed between the Ecole Nationale Supérieure (ENS), Lyon, and the Université Clermont Auvergne (UCA) in 2016 (internal document). 
writing (with a basic set constraint), the beneficial effect of oral philosophical discussion in pupils aged $7-12$ years (Auriac, 2007).

But what about written philosophical discussion? Can junior high school pupils be taught to write philosophically, even though philosophical writing has been thought feasible only in 12th grade, and then only in set exercises of the essay type?

\subsection{Definition of the 'Philosophical Writing' Genre}

Despite abundant literature on text genres (Bronckart, Bain, Scheuwly, Davaud, $\&$ Pasquier, 1985), there are no literature references defining the 'philosophical writing genre' adapted for young pupils (8 - 15 years). The literature on the subject (see Denat, 2007) mostly concerns pupils at senior high school (in $12^{\text {th }}$ grade at age 18, but also from age 16, cf. Means \& Voss, 1996; Neuman, 2003). Given this lack, we defined a priori what the philosophical genre could include (Auriac-Slusarczyk, Slusarczyk, \& Thebault, 2016), and tested this definition by collecting 315 scripts from 7th and 8th grade junior school pupils (Auriac-Slusarczyk, Slusarczyk, Thebault, \& Pironom, 2018). We validated the psycholinguistic indicators that enabled us if not to define, then at least to delimit what the philosophical genre could claim as proper by comparison (similarity/difference) with other text types, and also by the textual quality of the writing (presence of an introduction and a conclusion, appropriate length, etc.). A philosophical text contains a certain number of ideas (termed concepts) that are usefully differentiated (distinctions). The process of idea generation follows a line that is not only argumentatively strict, but also digressive in the positive sense of bringing into play creative thought, measurable with at least two indicators: the presence of features of divergence, and the presence of metaphors or analogies (see below).

At the age considered in this study, we can also expect pupils to be able to note down their ideas, thereby ordering their text, and through such conceptual ordering, go on to construct a full connected text: we can then measure the effective degree of ordering in the text on ordinal scales (cf. Auriac-Slusarczyk et al., 2018, Auriac-Slusarczyk, Slusarczyk, \& Thebault, 2017).

\subsection{From Collective Oral Work to Writing}

There is an abundant literature on written production including writing at school (MacArthur, Graham, \& Fitzgerald, 2006; Rijlaarsdam, Van den Berg, \& Couzijn, 2005; Alamargot \& Chanquoy, 2001). For the last ten years, researchers have used school pupil scripts (Gunnarsson-Largy \& Auriac-Slusarczyk, 2013), superseding earlier approaches (Fabre-Cols, 2004; Fabre, 1988). Work in psycholinguistics and text generation (Fenoglio \& Chanquoy, 2007) has made fruitful use of rough notes to study the ordering of pupils' writing, in particular creative ordering (Galbraith, 1999; Hayes, 1996). Releasing the pupils from constraints, and giving them open subjects, appears to be beneficial (Hayes, 2006). 
Developmentally, junior high school pupils are at a turning point: we know that young pupils ( 8 - 12 years) often write linearly even at the rough notes stage, and take little or no advantage of pre-ordered ideas (Auriac \& Favart, 2007; Auriac, 2007), whereas university students (older than 18 years) successfully use graphically structured notes, though still to a modest extent (Piolat, 2010; Piolat \& Barbier, 2007). Structuring notes and ordering ideas can take many forms: complete mind maps, tree diagrams, lists of ideas, arrows, indentation, etc. Lists are thought to have been among the earliest types of written texts (Olson \& Cole, 2006; Goody, 1979; Lahire, 1998). Readily understood by pupils, they are an intermediate writing form shown to be fruitful as early as age $7 / 8$ years (Démongin \& Cellier, 2002) and of direct utility, whether they are self-generated or imported, for pupils by age 13 years (Pouit \& Golder, 1997; 1996).

\subsection{Logical versus Creative Thought}

The use of fine arts in school teaching has been positively assessed (Kerlan, 2007). It is known that looking at artworks stimulates intuitive reasoning (Hayman, 1961). Philosophical and esthetic thinking share common ground: surprise, attention, confrontation, questioning, and problematization (Dalsuet, 2015). Lipman, the inventor of the collective practice of PDD (see Introduction) claimed that the expression of creative thinking required "amplifying thought" (Lipman, 2005: p. 241). He held that logical and creative thought should be linked (Lipman, 1991; Slade, 2000). The use of art is attracting new attention (e.g. Plucker \& Beghetto, 2015), including in science, through the advocacy of well-known researchers (Changeux, 2017). But we already knew that art and science go hand in hand, great scientists being no strangers to reverie and poetry (Bachelard, 1988). The study of writers' drafts likewise brings out strong links between rough sketch, outline, deletion and thematic recurrence, revealing a graphic and logical process of creation at work (e.g. Fenoglio, 2002).

PDD has demonstrated various beneficial effects: IQ gain, pacification of interactions among pupils, increased self-esteem and reduced anxiety (e.g. Millett \& Tapper, 2012): the effects observed thus often concern logical thinking or social skills, or the pupils' psychological state. Curiously, the benefits of PDD for pupils' creativity have been barely explored. It may be that the skills involved in PDD have been too readily reduced to the trio "conceptualize, problematize, argue" (cf. Tozzi model, see Calistri, Martel, \& Bomel-Rainelli, 2007), which does not fully embrace Lipman's initial model.

Creative thought, though not directly correlated to intelligence as measured by IQ tests (Besançon, Barbot, \& Lubart, 2011), is still very strongly supported by certain intellectual abilities, among which is divergent or "exploratory" thought (i.e. an all-out search for as many ideas or solutions as possible from a single starting point) (Besançon et al., 2011). In addition, we know that recourse to analogy (or metaphor) often backs logical reasoning (Hofstadter \& Sander, 2013). 


\subsection{A Designed and Tested Innovative Program: Philo \& Carto}

The program called Philo \& Carto (cf. Thebault, 2015) is based on oral philosophical practice conducted collectively according to the principles laid down by Lipman (support, collection of questions, choice of a collective question, and discussion); it also integrates the expertise of cartographers (Jacob, 1992), transposed to the school setting when finalizing the collective discussion in a map drawn together, inspired by the allegorical or satirical maps in use until the $19^{\text {th }}$ century (Baridon, 2011). The Carte de Tendre (Map of Tendre) engraved by Chauveau, 1659 is one of the best-known examples. The map represents ideas (affection, futility, love, etc.) by spatial features (landscape, places and pathways linking them). This type of representation thus engages the imagination and elicits surprise at a novel and apt use of images (Besse \& Thibergien, 2017). Maps are useful as simple charts to make our way in a complex modern world (Fabre, 2011) overloaded with information. It is here that the cartographer's thinking meets the philosopher's: in both cases, the aim is to build a representation of the world, expressed verbally by the philosopher, graphically by the cartographer. The Philo \& Carto program uses this concurrence. It was tested in primary school using suggestive artworks, engaging the pupils in collecting philosophical questions and extracting from the artwork pictorial features they could link to the ideas they had exchanged in the collective discussions (Thebault, 2015). This meeting of art and philosophical practice generates a collective map that culminates the whole process of enquiry. As in the case of the Carte de Tendre, where the cartographer imposes an allegorical style, e.g. creating the river of Esteem, or the river of Inclination, the Philo \& Carto program has the pupils link the ideas discussed (philosophical concepts) to salient pictorial features (percepts from an artwork): the pupils complete their work by drawing their own collective map (see Slusarczyk et al., 2017).

\section{Methodology}

\subsection{Participants}

Four 8th grade junior high school classes comprising 88 pupils used to PDD since the 6th grade took part in the program as experimental classes. The pupils were recruited in two schools in the same geographical area; the socioeconomic categories of their families were equivalent. The catchment sector was semi-rural. All the pupils in the 8th grade were considered: pupils were not selected to make up a strictly random sample. The teachers (French, history, geography and art) received training so they could follow a complete Philo \& Carto workshop (see $\$ 2.2$.). The purpose of the training was to introduce philosophical practice into interdisciplinary teaching spaces (EPIs), a new teaching framework introduced into official education guidelines in 2015 (M.E.N., 2015a, 2015b, 2015c). These teachers reproduced the program with their 8th grade pupils, working in twos in the EPI framework set up at the beginning of the 2016 school year in their school. The school heads had promoted the program and supported 
the experiment. The Philo \& Art EPIs ran for the first half-year between September and February. Three 8th grade junior high school classes comprising 77 non-PDD pupils took part in the program as controls, under the control school art teacher alone (same geographical sector and sociocultural mix as the experimental school). These control pupils were shown the eight artworks selected (see below) with ten minutes free verbal exchange on the artwork during art classes. The pupils were to comment freely on the artwork: impressions, perceptions. Table 1 summarizes information on the participants.

\subsection{The Philo \& Carto Protocol}

A Philo \& Carto workshop starts with the viewing of an artwork inducing short collective exchanges: first impressions and perceptions are elicited. At this stage, in conformance with how a philosophy workshop is conducted in reference to the work of Matthew Lipman, single individual questions are first collected, followed by the choice of a collective question that engages a collective PDD. During the discussion, the teacher extracts major ideas, limited in number to ten, representing the whole of 50 minutes of collective verbalization. The artwork is introduced again to select and extract ten pictorial items that characterize it and/or suggest a bridge with the ideas being discussed. Pictorial items can also be created and added to the initial artwork. The pupils then work on their collective map (called philocarte) in a large format for a presentation that preserves its collective character (see examples in \$2.6.). The art teacher participates in this production to lend it a satisfactory final appearance, while translating the pupils' drawings loyally, without embellishment or censure.

\subsection{Material Selected}

Out of 20 cultural heritage artworks preselected for their cultural and technical diversity (support, technique, figuration, time), the teachers retained eight. The choice was left free to respect teachers' independence and motivation (Table 2). This free choice also favored strict compliance with the action-research program over the whole of the half-year (October-February, 2016), which was monitored by means of a log recording the session details (choice of artwork, date, number of pupils, single questions, ten key pictorial ideas, ten constructed metaphors, scanned collective map).

\subsection{Pupils' Test Task for Writing}

In all, $169^{3}$ pupils produced written texts in the French class before and after experimentation with the program (pre-et post-test). The writing task consisted in presenting a reproduction of a work by the contemporary painter Etienne Cournault, La part du rêve ("the dream part"), pre-test (collective, 2016), and then a work of the contemporary painter Richard Texier Le chasseur d'étoiles ("the star hunter") 1999, post-test. The philosophical writing theme, which was open, was the same pre- and post-test: "dreaming". The pupils were given a plain ${ }^{3} 165$ at the end of the year, 4 pupils absent. 
Table 1. Subjects, numbers, levels, sectors.

\begin{tabular}{cccc}
\hline Numbers & Grade & Status & School sector \\
\hline 22 & 8 th & PDD & rurban \\
23 & 8 th & PDD & rurban \\
22 & 8 th & PDD & rurban \\
21 & 8 th & PDD & rurban \\
27 & 8 th & control & rurban \\
25 & 8 th & control & rurban \\
\hline
\end{tabular}

Table 2. The eight artworks selected for the experiment.

\begin{tabular}{|c|c|c|c|c|c|c|c|}
\hline Painting & Painting & Painting & Drawing & Photograph & Painting & Painting & Sculpture \\
\hline $\begin{array}{c}\text { The Tower of } \\
\text { Babelby } \\
\text { Pieter } \\
\text { Brueghel, oil } \\
\text { on wood } \\
\text { (1563). }\end{array}$ & $\begin{array}{l}\text { The Geographer } \\
\text { by Johannes } \\
\text { Vermeer, oil on } \\
\text { canvas } \\
(1668-69) .\end{array}$ & $\begin{array}{l}\text { The Subjugated } \\
\text { Reader by René } \\
\text { Magritte, oil on } \\
\text { canvas (1926). }\end{array}$ & $\begin{array}{l}\text { Long Live } \\
\text { Love by Niki } \\
\text { de St Phalle, } \\
\text { felt tip and } \\
\text { gouache } \\
\text { (1990) }\end{array}$ & $\begin{array}{l}\text { Passage by Robert } \\
\text { and Shana } \\
\text { Parke Harrison, } \\
\text { photograph } \\
\text { (1993-94) }\end{array}$ & $\begin{array}{c}\text { Anthropomorphic } \\
\text { Landscape by Joos de } \\
\text { Momper, oil on wood } \\
\text { (1610). }\end{array}$ & $\begin{array}{l}\text { Psyche and the } \\
\text { Golden Box by } \\
\text { John William } \\
\text { Waterhouse, oil } \\
\text { on canvas (1903) }\end{array}$ & $\begin{array}{l}\text { Storm King Wall } \\
\text { by Andy } \\
\text { Goldsworthy in } \\
\text { situ work } \\
(1997-1998)\end{array}$ \\
\hline
\end{tabular}

Images of all these works can be downloaded from the Internet.

box on an A4 sheet alongside the artwork to note down their ideas (rough notes), and subsequent lined pages to write out their text (Figure 1).

The pupils were invited, from an artwork (artistic reference anchor), to produce a piece of philosophical writing that could be published in a magazine meant for teenagers.

\subsection{Scoring of Writing}

As the literature does not fully describe the different ways in which pupils take notes (see above, \$1.2.), we made a basic distinction between lists and written-out text (see Auriac \& Favart, 2007), and then took account of how the pupils used lay-out in the space provided, in addition to listing (as one way of spatializing their notes vertically). The writing was thus scored by an inductive approach (D'Arripe, Oboeuf, \& Routier, 2014; Glaser \& Strauss, 2010; Blais \& Martineau, 2006). We collected the material and then determined the classification according to the variations obtained. The rough notes (left-hand page) produced were broken down qualitatively into seven structural types. Some types of rough notes were hybrid, half listed, half written-out, and so we could not place them in either single category. We opted for a finely-grained categorization to take full account of the quality of the rough notes. Our material finally fell into the following categories:

1) mind maps spatializing the ideas noted in words or short phrases with arrows and ranking,

2) lists with ideas presented in columns (listed words), or with indentations (bullet or dash), or separation by commas or semicolons, 


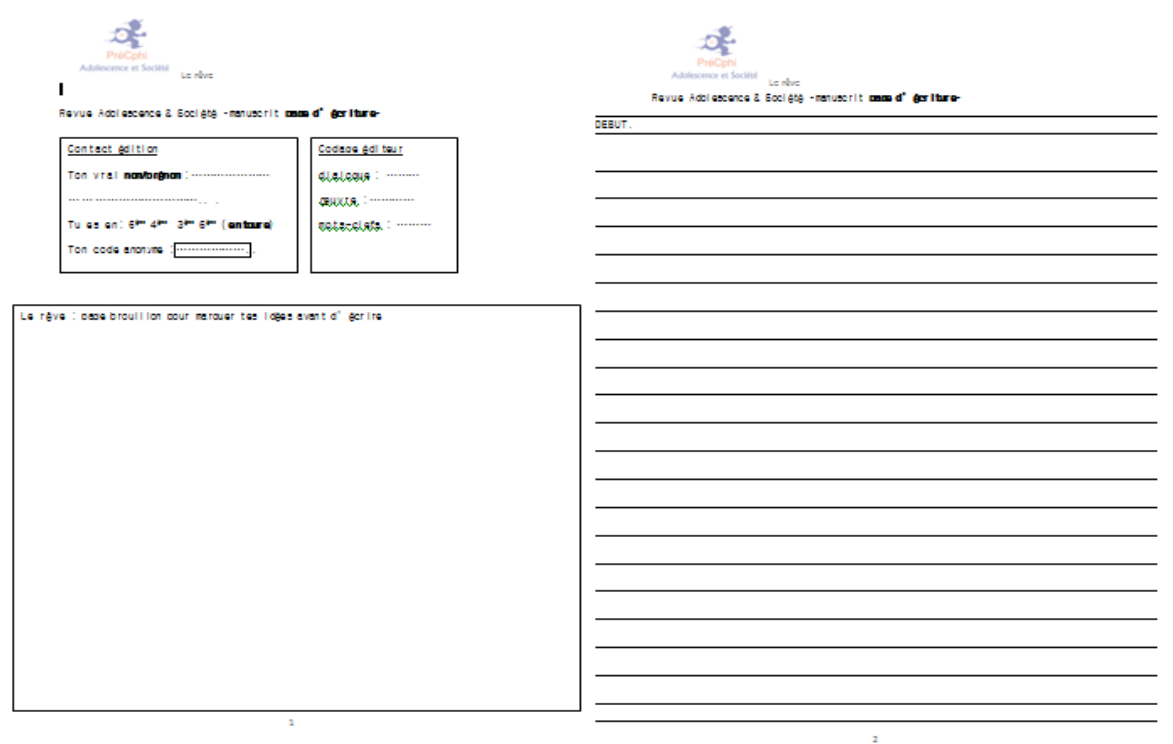

Figure 1. Standardized script sheets, rough notes and first text sheet.

3) written-out notes where the ideas are expressed in connected text, with no isolated words,

4) hybrids, written-out and then listed,

5) written-out lists, where chunks of connected text are listed,

6) spatialized notes, where the ideas presented are organized with key words distributed non-randomly in the space allotted (top, left, right, opposite, underneath, bottom, etc.),

7) absence of any rough notes, the pupils writing out their text directly on the lined page.

These different types of rough notes are illustrated in Results ( $\$ 3$ below). Subcategories then describe the specific features of control and experimental classes within a particular type: for example, a mind map can contain words naming concepts or pictorial items in ranging proportions.

\section{Results}

The results we report here concern the graphical productions of PDD pupils in four experimental classes, and a qualitative comparison of the rough notes in all seven classes, contrasting the control and experimental classes. Our findings prompted a theoretical formalization of the Philo \& Carto program as empirically validated in these junior high school classes.

\subsection{Graphic Productions of Pupils}

The teachers at the experimental school returned 24 "philocartes" (philosophy maps) (Figure 2).

The philocartes are the concrete result of the pupil/teacher joint effort. The logs attest the production of pupils' single or collective philosophical questions: for example, "Why can reality be frightening?" "Are we really in control of 


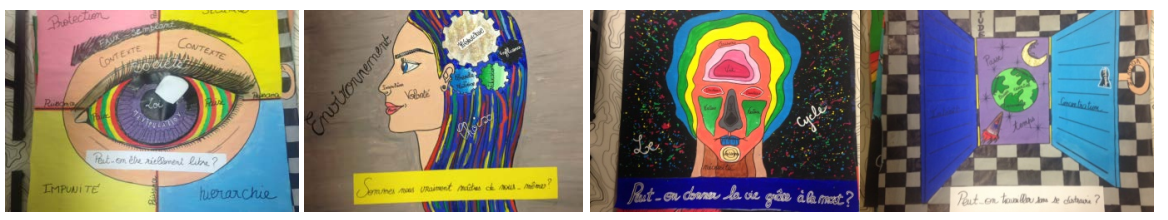

Figure 2. Examples of "philocartes" from four experimental 8th grade junior high school classes. All the productions in color are presented in Slusarczyk et al., 2017.

ourselves?" The creation of 240 expressions over the year in the four classes (e.g. eyes are ponds of pain) attests a complete appropriation of the approach by both teachers and pupils. The pupils even translated the justification for linking ideas and pictorial items into color: they proposed justifications such as: "the foliage will be red because "for me, red represents shade well, because it's the color of evil, of hell'.

\subsection{Intermediate Writing after Experimentation: Variety and Contrast}

Using the seven types of rough notes $(\$ 2.4$.), there was already a significant difference between experimental and control classes at the start of the year $\left(\chi^{2}(7\right.$, $166)=34.52, p<0.001)$ and a stronger one at the end of the experiment $\left(\chi^{2}(6\right.$, $165)=52.96, p<0.001$ ), which can be explained by the fact that the PDD pupils had already experienced PDD in 6th and 7th grade. Only the pupils in the experimental classes produced complete mind maps (Graph 1, see data source in Table 3 and Table 4). This quality of production could thus be ascribed at the start of the experiment to the prior experience of PDD in 6th and 7th grade, and at the end of the experiment to the influence of the Philo \& Carto program.

The class effect pre-test $\left(\chi^{2}(42,169)=152.68, p<0.001\right)$ diminished slightly at the end of the experiment $\left(\chi^{2}(36,165)=142.97, p<0.001\right)$ indicating influence either of the program or of class composition (Table 3 and Table 4 below): the non-PDD control class E1 stood out, the pupils in it making use of written-out rough notes pre- and post-test; the experimental PDD group G4 stood out, with 13 pupils already using complete mind maps pre-test. Noteworthy results are highlighted in the tables (data sources, Table 3 and Table 4).

By contrast, the experimental class G1 changed its writing approach, with only 1 mind map produced pre-test against no fewer than 14 post-test; the control class E2 where 11 pupils wrote out their ideas pre-test, varied more widely in their choice post-test, although there was more absence of notes (10 pupils) and no mind maps.

\subsection{Experimental Classes: Mind Maps and Ideas Written Out as Concepts}

Four subcategories of mind maps were identified in the experimental classes (Figures 3(a)-(d)). We note that the PDD pupils emphasized philosophical concepts more often than pictorial items: they mentioned sorrow, or good or beautiful (Figure 3(a)), psychological state, and unconscious (Figure 3(b)). 
Table 3. Data source: distribution of types of rough notes pre-test by class.

\begin{tabular}{cccccccccc}
\hline & & \multicolumn{7}{c}{ IDENTIFICATION OF CLASSES } & \multirow{2}{*}{ Total } \\
\cline { 3 - 8 } & & E1 & E2 & E4 & G1 & G2 & G3 & G4 & \\
\hline \multirow{2}{*}{$\begin{array}{c}\text { Nypes } \\
\text { Non-coded }\end{array}$} & 0 & 2 & 0 & 1 & 0 & 1 & 2 & 6 \\
$\begin{array}{c}\text { Absence } \\
\text { produch notes } \\
\text { pre-test }\end{array}$ & 0 & 5 & 0 & 6 & 2 & 7 & 2 & 22 \\
& Written-out & 20 & 11 & 7 & 6 & 5 & 10 & 1 & 60 \\
& Written-out/listed & 3 & 0 & 0 & 3 & 1 & 1 & 0 & 8 \\
& Listed & 1 & 3 & 7 & 3 & 6 & 3 & 2 & 25 \\
& Written-out list & 3 & 6 & 10 & 0 & 6 & 0 & 1 & 26 \\
& Spatialized & 0 & 0 & 2 & 2 & 0 & 0 & 1 & 5 \\
& Mind map & 0 & 0 & 0 & 1 & 3 & 0 & 13 & 17 \\
& Total & 27 & 27 & 26 & 22 & 23 & 22 & 22 & 169 \\
\hline
\end{tabular}

Classes E1 E2 E4 were controls, classes G1 G2 G3 G4 were experimental.

Table 4. Data Source: distribution of types of rough notes post-test by class.

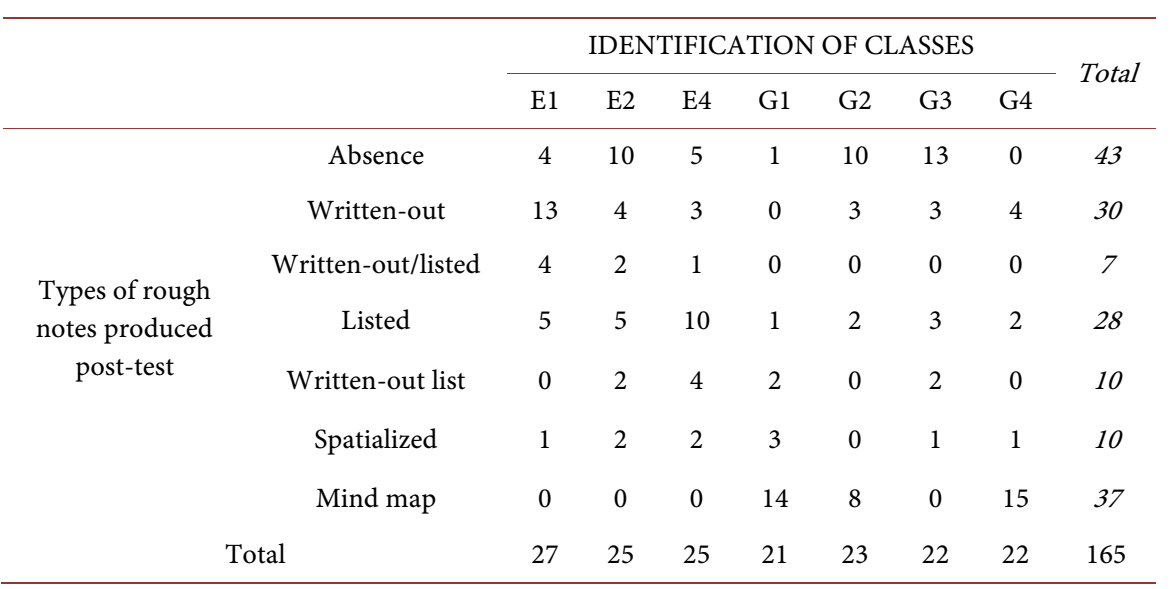

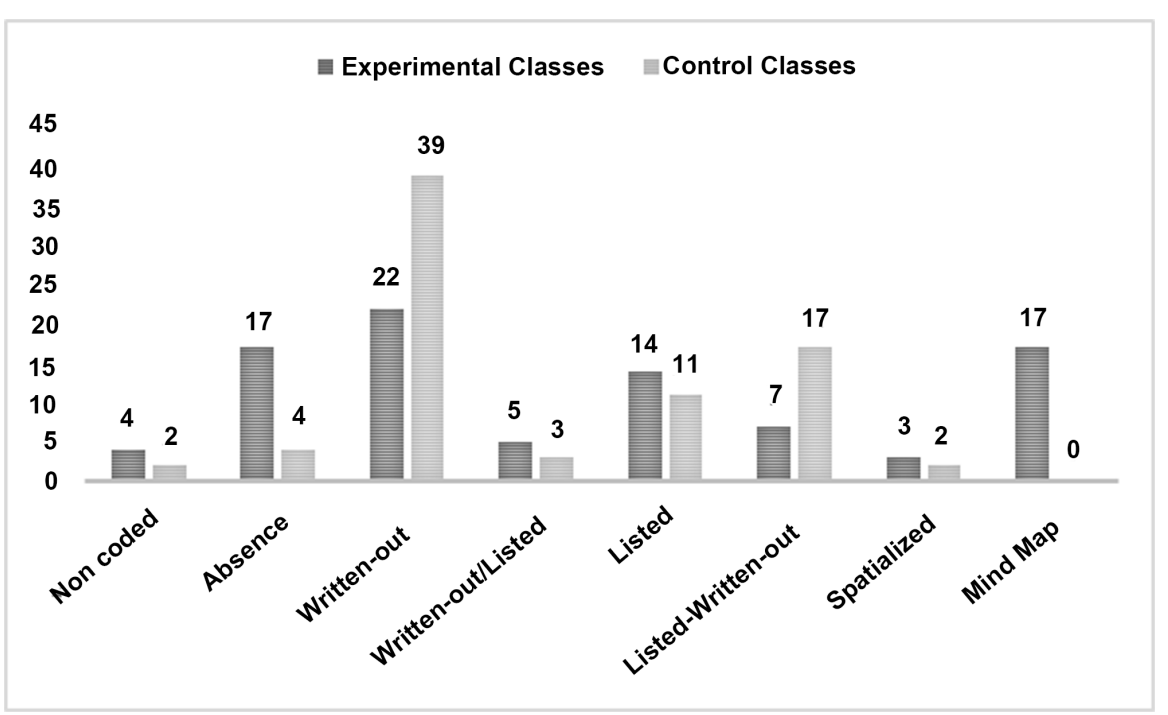

Graph 1. Distribution of each type of rough notes by class type pre-test.

${ }^{4}$ Data missing. 


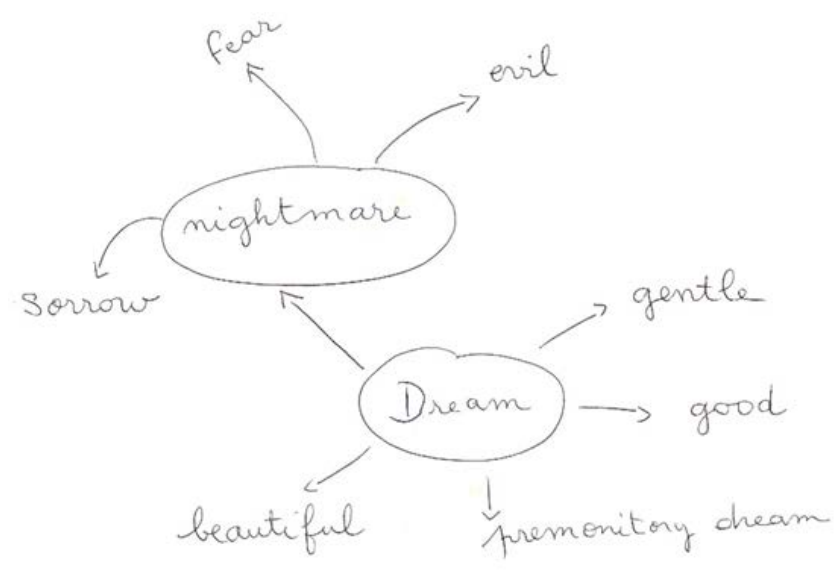

(a)

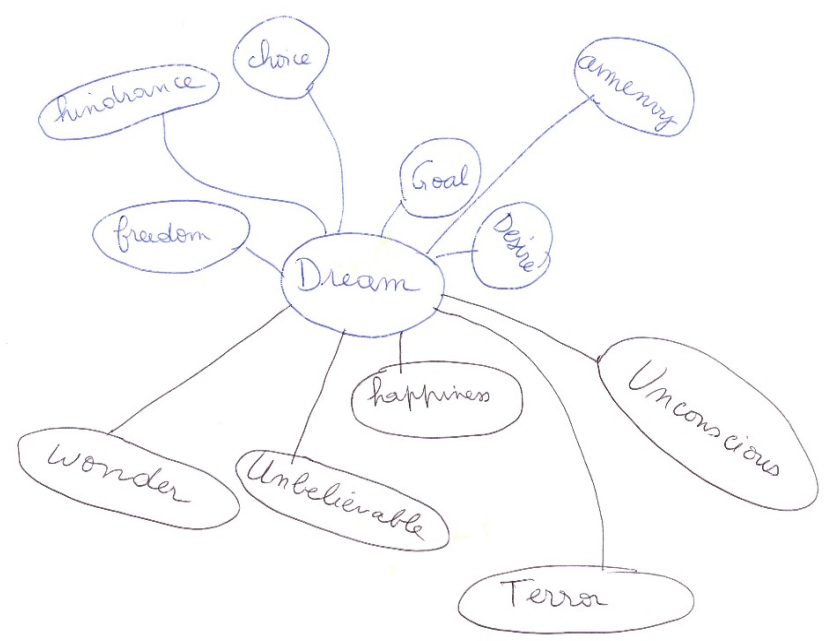

(c)

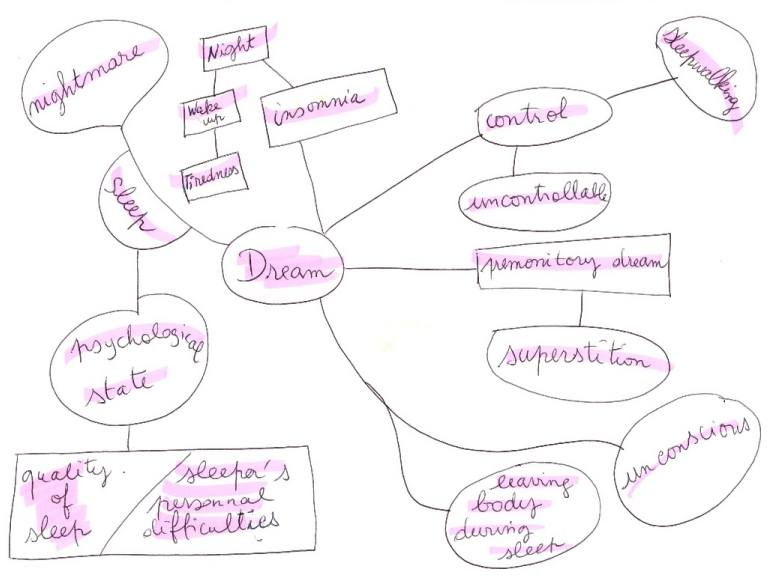

(b)

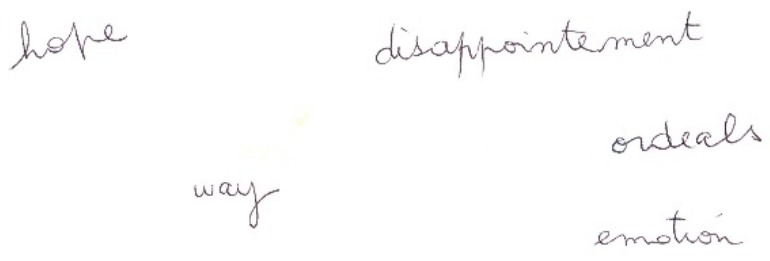

(d)

Figure 3. Subcategories of originals mind maps $(\mathrm{a} / \mathrm{b} / \mathrm{c})$ in experimental classes. (a) Basic original mind map rough notes (concepts); (b) Color-coded original mind map rough notes ${ }^{5}$ with concepts; (c) Binary-type mind original map rough notes (color ${ }^{6}$ and spatial bi-partition); (d) Spatialized original rough notes (concepts).

Sometimes the mind map subdivided the space in a binary way, with a frontier separating two worlds, with the help of an implicit color code. The world of wonder, the unbelievable, terror, happiness and the unconscious was separated from the world of freedom, hindrance, choice, aim, envy and desire, associated with dream (Figure 3(c)).

Lastly, the use of space indicates a new mode of distributing, ranking and organizing ideas: path is bottom center, hope is top left, opposite disappointment top right, etc. (Figure 3(d)).

These modes of spatial organization are not random but translate a conceptual ordering that evokes a higher stage of intellectual development (age 18 years and more) in these pupils aged 13 - 14 years (cf. Piolat, 2010, Piolat \& Barbier, 2007). ${ }^{5}$ The gray part was pink on the original script.

${ }^{6}$ On the original script, the seven words, circles and links at the top were blue, the five at the bottom (wonder, unbelievable, happiness, terror, unconsciousness), were black. 


\subsection{Control Classes: Lists, Connected Text and Predominant Specification of Pictorial Items}

The pupils in the control classes preferred either of two alternative configurations: lists or connected text (Graph 1 and Graph 2, and Figures 4(a)-(c) below); few pupils opted for spatialization (Figure 4(c) below). Their note-taking referred almost exclusively to figurative items found in the supporting artwork ( $\mathrm{La}$ part du rêve versus Le chasseur d'étoiles). The pupils detailed or listed the pictorial items in the artwork (astrologer, sun) and retrieved remembered cultural or scientific knowledge (Léonard de Vinci, Eclipse). They did not interpret the work conceptually.

Space was used in Figure 3(c), the pupil using a synthetic form in the concluding expression at the bottom: "the dreams Léonard de Vinci had", presumably meant to contain everything noted in the space above, ordered in a way that eludes the reader but which makes sense to the pupil: Léonard de Vinci top left, opposite eclipse, then terror, sketch and gearwheels in the middle, and on the bottom line fire, shade, knight and galaxy.

The non-PDD control pupils thus demonstrated their skill in generating impressionistic and perceptive ideas. The reference to writing in a magazine for teenagers seems to have been inoperative.

\subsection{Experimental Classes: Traces of Conceptual Ranking and Reasoning}

The rough notes produced in the experimental class quite often showed hyperonym/hyponym ranking (Figure 4), showing that the ordering of ideas engaged the pupil in more complex organizational modes than the simple use of nomenclature, or distinction of opposites. These pupils used "sunburst" forms for idea generation from clearly designated subsumed concepts (circled key words, here

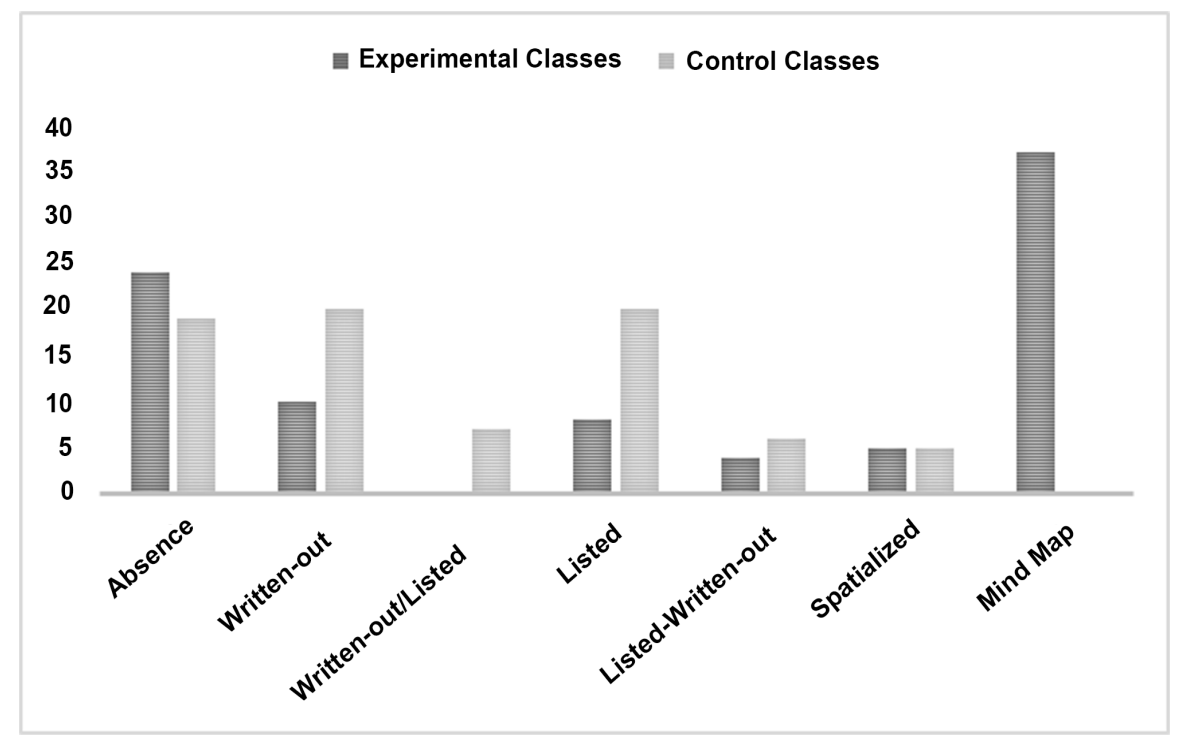

Graph 2. Distribution of each type of rough notes by class type post-test. 


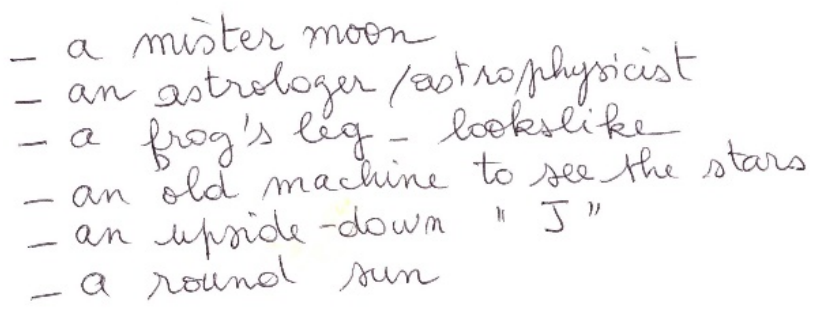

(a)

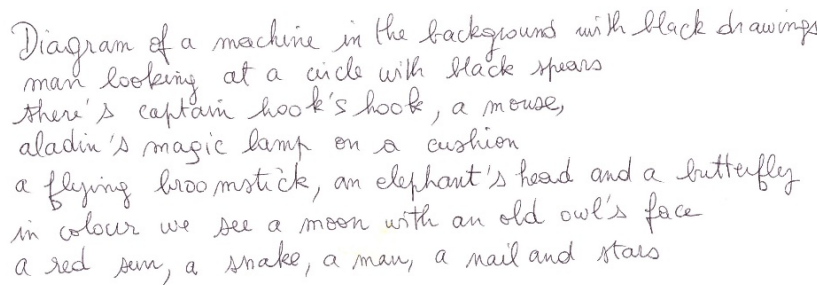

(b)

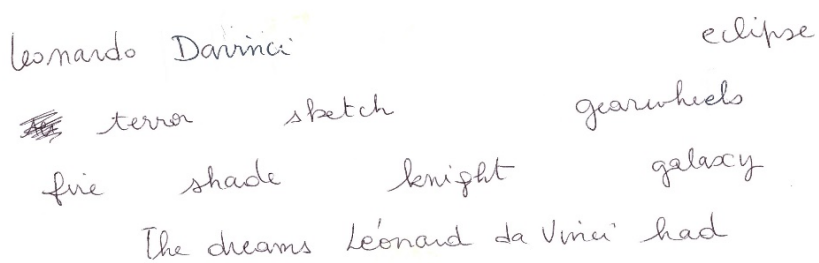

(c)

Figure 4. Representative types $(\mathrm{a} / \mathrm{b} / \mathrm{c}$ ) of rough notes in control classes. (a) Listed original rough notes (pictorial items); (b) Written-out original rough notes (pictorial items, imagination); (c) Spatialized original rough notes (pictorial items, imagination).

sleeping, dream, daydream, nightmare, wake up), developed by further detailed extension.

Rough notes in an experimental class presented in a list format attests an intellectual pathway that can be followed: starting with an initial concept (dream), set down as a premise with an explanation (a dream is "something we'd like to have"), the pupil progressively adds, stepwise, distinct opposing ideas (destiny, limits, freedom), and then comes back to the artwork to extract a pictorial item (the chair), and concludes that dreaming is confusion (Figure 5).

This pupil made an individual use of the Philo \& Carto approach, going back and forth between ideas and pictorial items, even though we can question the conceptual basis that leads to the conclusion. But the pupil offers an interpretation of the artwork.

\subsection{Analysis of Contrast between Experimental and Control Classes}

Although we consider that the comparison between classes (experimental and controls) needs further validation (see conclusion and limitations below), a clear trend emerges that points to a fundamental difference between the two types of class. Pupils schooled in the usual way (controls), made aware of art by looking at artwork and using free personal expression, tended to favor mere description (Figure 4(a)/Figure 4(b)). By contrast, pupils used to philosophical discussion, who had been taught to question representations, tended to structure ideas taken from artworks, link them explicitly, favor distinctions and thus bring into play a more complete or even fully formed mental conceptual organization. Associating philosophically directed practices with consideration of artworks prompted pupils not only to reflect, but also to rank their impressions, and gradually to put 


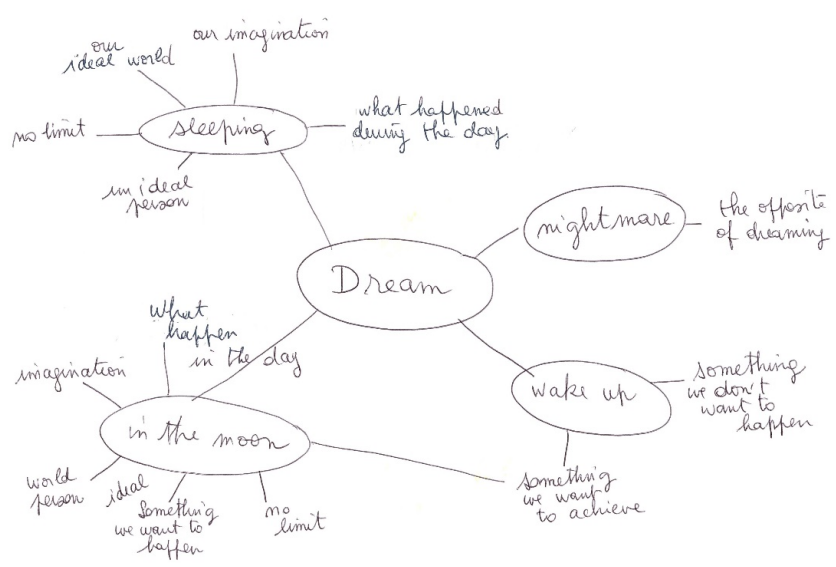

(a)

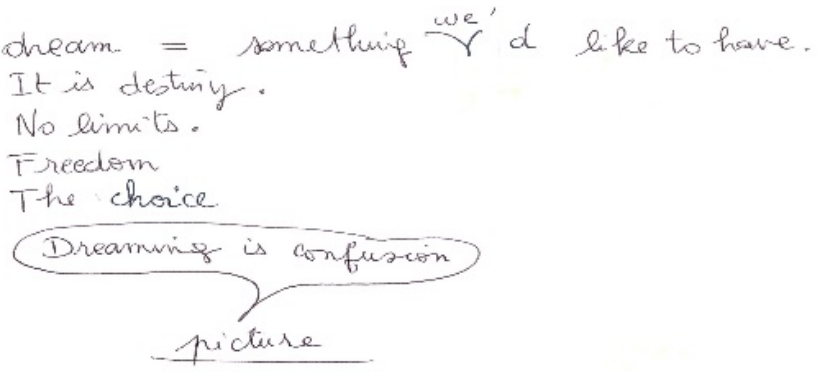

(b)

Figure 5. (a) Example of original hyperonym/hyponym rough notes in an experimental class; (b) Example of original rough notes with spatialized reasoning, experimental class.

aside impressions (often descriptive) in favor of classifications (hyponyms/hyperonyms), supporting a richer intellectual journey. In their rough notes taken before writing, the PDD pupils showed an ability to combine imagination and reflection judiciously, and use lay-out and color (Figure 3(b)/Figure $3(c))$ in their mind mapping to help chart more complex reasoning.

\section{Discussion}

The results of this exploratory study primarily emphasize differences between pupils used to or unused to PDD in how they order their ideas before writing a text (\$3.2.). The large proportion of rough notes, produced in the form of mind maps, in the experimental classes attests to the conceptual content and ranking of the ideas produced (\$3.5.), showing that these pupils used to philosophical discussion at school had reached a high level of expertise for their age, confirming the positive impact of the practice of philosophical discussion measured in terms of acceleration of development (Mortier, 2005, Millett \& Tapper, 2012). The pre-test interclass variability (\$3.2.) argues for extending our data to determine whether the rough notes can be related to the ensuing texts (see Maire, Auriac-Slusarczyk, \& Slusarczyk, 2018, Maire, Auriac-Slusarczyk, Pironom, \& Slusarczyk, 2018); rough notes organized from conceptual items (\$3.5.) versus pictorial items (\$3.4.) does not necessarily guarantee a better quality text. Hence the Philo \& Carto experimental program needs an advanced theoretical formalization (see below) so as to be able to measure its specific effects; as the instructions given the pupils in experimental classes versus controls from the same eight artworks produced different effects post-test (\$3.4./3.5.), we need to know the extent to which the artwork, as a reference support, induces a creative process of interest to 1) the teaching of art, and 2) fostering creative philosophical thought (Chabanne, Parayre, Villagordo, \& Daquin, 2011; Leckey, 2017; Slusarczyk et al., 2017; Auriac-Slusarczyk, Daniel, Fiema, Pironom, \& Belghiti, 
2017). Creative thinking is underpinned by certain intellectual capacities, among which divergent or exploratory thought (i.e., all-out search for as many ideas or solutions as possible from a single starting point, see Besançon, Barbot, \& Lubart, 2011) can be found here in rough notes of the spatialized or mind map types.

\section{Toward a Theoretical-Empirical Formalization of the Philo \& Carto Program}

The repeated creation of metaphors (Margel, 2006; Lakoff \& Johnson, 1980) is an important feature of the Philo \& Carto program offered to PDD pupils. The description of the program could thus be reduced to the philosophical and linguistic/language dimensions only. However, we propose here a reverse formalization of the Philo \& Carto program, as validated empirically, depicted below (Figure 6).

The pupils' engagement in the Philo \& Carto program obliges them to explore, at the same time, philosophy (in a collective setting), and esthetics (of the proposed artwork, see Plucker \& Beghetto, 2015), linguistics (which supports the creation of metaphoric expression, see $\$ 1.4$.), and lastly geography and cartography, where the production of the philocartes illustrates the expertise gained by the pupils (see \$3.1.) Analogical reasoning (cf. Hofstadter \& Sander, 2013) seems central to the program, helping to bring together the four explored fields (philosophy, cartography, linguistics and esthetics), and make them interdependent: this is evident in the rough notes produced by the PDD pupils in which mind mapping is used to order complex ideas. The ideas set down are not merely listed words, but are nodes in a network, in a system of explicit links represented graphically in the rough notes (arrows, circling, ranking, spatialization), in which the ordering of hyperonyms and hyponyms (\$3.5.) attests to a strong intellectual organization (Berten, 2017). Further studies will validate or challenge this theoretical-empirical formalization of our Philo \& Carto program, and thus offer new perspectives on the links between art, creativity and education (Plucker \& Beghetto, 2015).

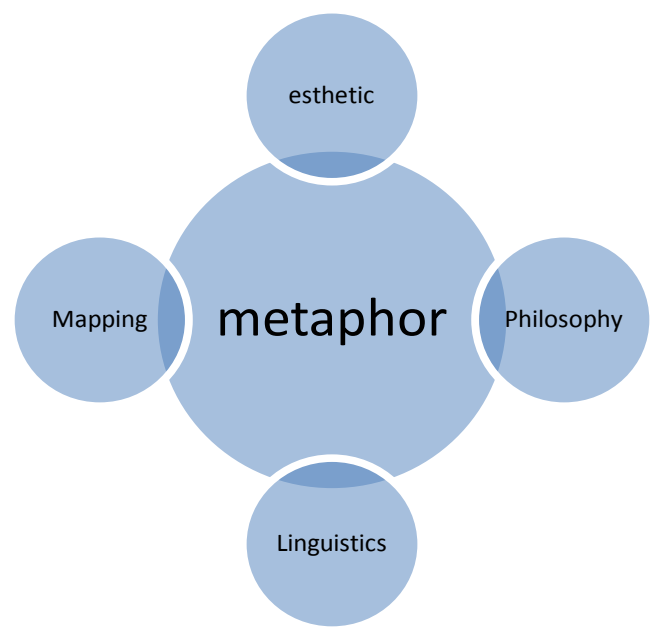

Figure 6. Formalization of the Philo \& Carto program. 


\section{Conclusion and Limitations of the Study}

These first results raise a question: if junior high school pupils used to PDD reach a level of conceptual and organizational expertise in generating ideas, is this a motivational-conjunctural effect, or a true developmental advancement? The effects due to earlier practice of PDD and those of the Philo \& Carto program are confounded in this study. In addition, a fatigue effect (due to testing and retesting writing on the same theme, dreaming), may not have acted in the same way according to the conditions tested (PDD or non-PDD classes). This fatigue effect is a second factor that crosses with the results presented here. Furthermore, we did not consider the pupils' level of attainment; the link between organization of ideas and intellectual level warrants investigation (cf. Slusarczyk, Fiema, Auriel, \& Auriac-Slusarczyk, 2015; Çokluk-Bökeoğlu, 2008). Lastly, the junior high school pupils, some of whom were ready to generate mind maps at the start of the experiment, may have developed feelings of self-efficacy that might explain why the PDD classes sought to move on to written work at the end of $7^{\text {th }}$ grade (see the experimental context in the Introduction). Hence, many aspects remain to be explored, calling for further research. Within the limitations of the present work, studying pupils' rough notes to follow the writing process (cf. Fenoglio \& Boucheron-Pétillon, 2002) is useful for rethinking writing aids in education. In our case, teaching experiments conducted in the interdisciplinary teaching spaces recently introduced by the French Ministry of Education to impel school innovation in a supervised and controlled way, seem to be positive and beneficial for pupils practicing PDD in experimental classes.

\section{References}

Alamargot, D., \& Chanquoy, L. (2001). Through the Models of Writing. Dordrecht: Kluwer Academic Publishers. https://doi.org/10.1007/978-94-010-0804-4

Auriac, E. (2007). Effet de discussions à visée philosophique sur le processus de génération d'idées. Enfance, 2007, 356-370. https://doi.org/10.3917/enf.594.0356

Auriac, E., \& Favart, M. (2007). Passage d'un avant texte au texte dans des écrits scolaires de type argumentatif. Langue Française, 115, 69-83. https://doi.org/10.3917/lf.155.0069

Auriac-Slusarczyk, E., \& Maufrais, M. (2010). Chouette! Ils philosophent. Encourager et cultiver la parole des écoliers. Paris/Clermont: Scérén-CRDP Auvergne.

Auriac-Slusarczyk, E., Daniel, M.-F., Fiema, G., Pironom, J., \& Belghiti, K. (2017). Verbal Manifestation of Critical Thought. Transversal Study from Age 10 to 18 in France. World Journal of Education, 7, 38-56. https://doi.org/10.5430/wje.v7n6p38

Auriac-Slusarczyk, E., Slusarczyk, B., \& Charles-Beaucourt, I. (2011). Et si un peu de philosophie contribuaient au bien-être des collégiens? Diotime, 49, publié 07/2011.

Auriac-Slusarczyk, E., Slusarczyk, B., \& Thebault, C. (2016). La constitution d'un corpus d'écrits scolaires utile aux SHS. Premiers écrits philosophiques au collège. Enseignement et apprentissage de l'écriture de la maternelle à l'université et dans les formations tout au long de la vie Bordeaux, France, 19-21 October.

Auriac-Slusarczyk, E., Slusarczyk, B., \& Thebault, C. (2017). Premiers écrits philosophiques en primaire: Qualité rédactionnelle, créativité \& divergence. In $2 e$ Symposium international sur la littératie à l'école, SILE /ISEL. Ajaccio, Corse, France. 
Auriac-Slusarczyk, E., Thebault, C., Slusarczyk, B., \& Pironom, J. (2018). Premiers écrits philosophiques à l'école primaire. Productivité conceptuelle et créativité rédactionnelle du CE2 au CM2. Bulletin de Psychologie, 71, 671-690.

Bachelard, G. (1988). Fragments d'une poétique du feu. Établissement du texte, avant-propos et notes par Suzanne Bachelard. Paris: Presses universitaires de France. http://classiques.uqac.ca/classiques/bachelard_gaston/Fragments_une_poetique_du_fe u/Fragments_poetique_du_feu.pdf

Baridon, L. (2011). Un atlas imaginaire. Cartes allégoriques et satiriques. Paris: Citadelles \& Mazenod.

Berten, F. (2017). La notion de mots-clefs et sa difficile application pédagogique. Commission français et informatique en ligne. http://users.skynet.be/ameurant/francinfo/motcle/motcle.html

Besançon, M., Barbot, B., \& Lubart, T. (2011). Évolution de l'évaluation de la créativité chez l'enfant de Binet à nos jours. Recherches et Educations, 5, 215-226.

Besse, J.-M., \& Thibergien, G.-A. (2017). Opérations cartographiques. Paris: Actes Sud.

Blais, M., \& Martineau, S. (2006). L'analyse inductive générale: Description d'une démarche visant à donner un sens à des données brutes. Recherches Qualitatives, 26, $1-18$.

Bronckart, J.-P., Bain, D., Schneuwly, B., Davaud, C., \& Pasquier, A. (1985). Le fonctionnement des discours: Un modèle psychologique et une méthode d'analyse. Neuchâtel: Delachaux \& Niestlé.

Calistri, C., Martel, C., \& Bomel-Rainelli, B. (2007). Apprendre à parler, apprendre à penser: Les ateliers de philosophie. Paris: Sceren.

Chabanne, J.-C., Parayre, M., Villagordo, E., \& Daquin, P. (2011). Premiers pas dans la parole sur l'œuvre: Observer, interpréter et guider les conduites langagières comme compétence professionnelle. Repères, 43, 77-102. https://doi.org/10.4000/reperes.218

Changeux, J.-P. (2017). La beauté dans le cerveau. Rencontre de l'Art et des neurones. Paris: O. Jacob.

Chauveau, F. (1659). Carte du Pays du Tendre, 1659, 38,5 x 48,5cm. Paris: Bibliothèque nationale de France, département des estampes, visuel accessible sur. https://www.lettresvolees.fr/montpensier/documents/Tendre.pdf

Çokluk-Bökeoğlu, Ö. (2008). Testing Factor Structure of California Measure of Mental Motivation Scale, in Turkish Primary School Students and Examining Its Relation to Academic Achievement. World Applied Sciences Journal, 4, 94-99.

Collective (2016). Etienne Cournault, la part du rêve, 1891-1947. Nancy/Nantes: Musée des Beaux-Arts.

D’Arripe, A., Oboeuf, A., \& Routier, C. (2014). L'approche inductive: Cinq facteurs propices à son émergence. Approches inductives en communication sociale, 1, 96-124. http://id.erudit.org/iderudit/1025747ar/DOI10.7202/1025747ar

Dalsuet, A. (2015). Art \& Philosophie. Paris: Ed. Palette.

Daniel, M.-F. (1992/1997). La philosophie avec les enfants. Brussels: De Boek \& Belin; Reed. 1997.

Daniel, M.-F. (2008). Présupposés philosophiques et pédagogiques de Matthew Lipman et leurs applications. In C. Leleux (Ed.), La philosophie pour enfants. Le modèle de Matthew Lipman en discussion (pp. 25-45). Brussels: De Boeck.

Démongin, P., \& Cellier, M. (2002). La liste, un écrit réflexif? In J.-C. Chabanne, \& D. Bucheton (Eds.), Parler et écrire pour penser, apprendre et se construire (pp. 73-98). 
Paris: PUF.

Denat, C. (2007). Au delà des textes: La question de l'écriture philsophique. Reims: Ed EPURE, Editions et Presses universitaires de Reims.

Fabre, C. (1988). Aspects de la production du texte dans les brouillons d'écoliers. Etudes de linguistiques appliquées, 71, 54-74.

Fabre, M. (2011). Éduquer pour un monde problématique. La carte et la boussole. Paris: Presses Universitaires de France.

Fabre-Cols, C. (2004). Brouillons scolaires et critique génétique: Nouveaux regards, nouveaux égards? Linx, 51, 13-24. http://linx.revues.org/160 https://doi.org/10.4000/linx.160

Fenoglio, I. (2002). Une photo, deux textes, trois manuscrits. L'archivage linguistique d'un geste d'écriture identifiant. Langages, 147, 56-69. https://doi.org/10.3406/lgge.2002.2412

Fenoglio, I., \& Boucheron-Pétillon, S. (2002). Processus d'écriture et marques linguistiques (No. 147). Paris: Larousse.

Fenoglio, I., \& Chanquoy, L. (2007). Avant le texte: Les traces de l'élaboration textuelle, langue française (No. 155).

Fiema, G. (2015). Étude des mouvements de pensée collective lors des ateliers philosophiques au primaire et au collège: extraction de philosophèmes en tant que structures formelles de raisonnement. Doctoral Thesis, Aubière: Université Blaise Pascal.

Fougères, R. (2016). Rapport Final Mission Institut Carnot de l'Education. Définition-expérimentation-Essaimage (165 p.). Report of Ministère de l'Enseignement Supérieur et de la Recherche, MNESER.

Galbraith, D. (1999). Writing as a Knowledge Constituting Process. In G. Rijlaarsdam, E. Espéret, M. Torrance, \& D. Galbraith (Eds.), Studies in Writing: Vol. 4. Knowing What to Write: Conceptual Processes in Text Production (pp. 139-160). Amsterdam: Amsterdam University Press.

Glaser, B. G., \& Strauss, A. L. (2010). La découverte de la théorie ancrée. Stratégies pour la recherche qualitative. Paris: Armand Colin.

Goody, J. (1979). La Raison graphique. La domestication de la pensée sauvage. Paris: Éditions de Minuit.

Gregory, M.-R., Hayes, J., \& Murris, K. E. (2017). The Routledge International Handbook of Philosophy for Children. London, New York, NY: Routledge Taylor \& Francis Group.

Gunnarsson-Largy, C., \& Auriac-Slusarczyk, E. (2013). Ecriture et réécriture chez les élèves. Un seul corpus, divers genres discursifs et méthodologies d'analyse. In Academia-Bruylant (Ed.), Coll. «Sciences du langage. Carrefour et points de vue», No. 10, Paris.

Hayes, J.-R. (1996). A New Framework for Understanding Cognition and Affect in Writing. In C. M. Levy, \& S. Ransdell (Eds.), The Science of Writing: Theories, Methods, Individual Differences and Applications (pp. 1-27). Mahwah, NJ: Lawrence Erlbaum Associates.

Hayes, J.-R. (2006). New Directions in Writing Theory. In C.-A. MacArthur, S. Graham, \& J. Fitzgerald (Eds.), Handbook of Writing Research (pp. 28-40). New York, NY, London: The Guilford Press.

Hayman, D. A. (1961). L'art dans la vie de l'Homme. Le Courrier de l'UNESCO, XIVI, 7-24. 
Hofstadter, D., \& Sander, E. (2013). L'analogie au cour de la pensée. Paris: O. Jacob.

Jacob, C. (1992). L'empire des cartes. Approche théorique de la cartographie à travers l'histoire. Paris: Albin Michel.

Kerlan, A. (2007). L'art pour éduquer. La dimension esthétique dans le projet de formation postmoderne. Éducation et sociétés, 19, 83-97. https://doi.org/10.3917/es.019.0083

Lahire, B. (1998). L'homme pluriel, Les ressorts de l'action. Essais et Recherche, Paris: Nathan.

Lakoff, G., \& Jonhson, M. (1980). Les métaphores dans la vie quotidienne. Paris: Editions de Minuit.

Leckey, M. (2017). Guernica Comes to School. Art, Philosophy and Life. In M. Gregory, J. Hayes, \& K. Murris (Eds.), The Routledge International Handbook of Philosophy for Children (pp. 137-144). London \& New York, NY: Routledge.

Leleux, C. (2005). La philosophie pour enfants. Le modèle de Matthew Lipman en discussion. Brussels: DeBoeck \& Larcier.

Lipman, M. (1991). Thinking in Education, traduction, N. Decostre, A l'école de la pensée. Brussels: De Boeck Université. Rééd2011.

Lipman, M. (1995). Thinking in Education, Traduction, N. Decostre, A l'école de la pensée. Brussels: De Boeck Université. Rééd2011.

Lipman, M. (2005). Renforcer le raisonnement et le jugement par la philosophie. In C. Leleux (Ed.), La philosophie pour enfants. Le modèle de Matthew Lipman en discussion (pp. 11-24). Brussels: De Boeck Université.

Lipman, M., Sharp, A.-M., \& Oscanyan, F. S. (1980). Philosophy in the Classroom. Philadelphia, PA: Temple University Press.

MacArthur, C.-A., Graham, \& Fitzgerald, J. (2006). Handbook of Writing Research. New York, NY, London: The Guilford Press.

Maire, H., Auriac-Slusarczyk, E., \& Slusarczyk, B. (2018). La pratique philosophique à l'oral transforme-t-elle l'écriture spontanée des élèves? Etude d'écrits au primaire et au collège chez des élèves tout venant versus philosophant. In 29th International Congres of Applied Psychology. Montréal, Canada.

Maire, H., Auriac-Slusarczyk, E., Pironom, J., \& Slusarczyk, B. (2018). La pratique philosophique à partir d'œuvres d'art en collège: Effets sur les performances langagières et créatives à l'écrit, 23e Journées Internationales de Psychologie Différentielle, Université of Luxembourg, 4-6 July 2018.

Margel, S. (2006). La métaphore. De la langue naturelle au discours philosophique. Rue Descartes, 52, 16-26. https://doi.org/10.3917/rdes.052.0016

Means, M., \& Voss, J.-F. (1996). Who Reasons Well? Two Studies of Informal Reasoning among Students of Different Grade, Ability, and Knowledge Levels. Cognition and Instruction, 14, 139-178. https://doi.org/10.1207/s1532690xci1402_1

Millett, S., \& Tapper, A. (2012). Benefits of Collaborative Philosophical Inquiry in Schools. Educational Philosophy and Theory, 44, 546-567.

https://doi.org/10.1111/j.1469-5812.2010.00727.x

Ministère de l'Education Nationale M.E.N. (2015a). L'enseignement moral et civique (EMC). Bulletin Officiel spécial du 25 juin 2015.

Ministère de l'Education Nationale M.E.N. (2015b). Le référentiel du parcours d'éducation artistique et culturelle. Bulletin Officiel du 09 juillet 2015.

Ministère de l'Education Nationale M.E.N. (2015c). L'organisation des enseignements au 
collège, Decret n 2015-544 et arrêté du 19 mai 2015. Journal officiel du 20 mai 2015, Bulletin officiel du 28 mai 2015.

Mortier, F. (2005). Etudes d'évaluation: La méthode de Matthew Lipman comme moyen de développement. In C. Leleux (Ed.), La philosophie pour enfants (pp. 47-69). Brussels: De Boeck Université.

Neuman, Y. (2003). Go Ahead, Prove That God Does Not Exist! On High School Student's Ability to Deal with Fallacious Arguments. Learning and Instruction, 13, 367-380. https://doi.org/10.1016/S0959-4752(02)00011-7

Olson, R. D., \& Cole, M. (2006). Technology, Literacy and the Evolution of Society: Implications of the Work of Jack Goody. Mahwah, NJ: Lawrence Erlbaum.

Piolat, A. (2010). Approche cognitive de la prise de notes comme écriture de l'urgence et de la mémoire externe. Le français aujourd'hui, 170, 51-62. https://doi.org/10.3917/lfa.170.0051

Piolat, A., \& Barbier, M.-L. (2007). De l'écriture elliptique estudiantine: Analyse descriptive de prises de notes et de brouillons. Langue française, 155, 84-100.

Plucker, J.-A., \& Beghetto, R.-A. (2015). Special Issue Editor-Creativity and Education, Introduction to the Special Issue. Psychology of Aesthetics, Creativity, and the Arts, 9, 113-114. https://doi.org/10.1037/aca0000020

Pouit, D., \& Golder, C. (1996). Peut-on faciliter l'argumentation écrite ? Effets d'un schéma de texte, d'une liste d'idées et d'un thème familier. Archives de Psychologie, 64, 179-199.

Pouit, D., \& Golder, C. (1997). Il ne suffit pas d'avoir des idées pour défendre un point de vue. La récupération des idées peut-elle faciliter la production écrite d'une argumentation chez les enfants de 11 à 17 ans. Revue de Psychologie de l'Education, 3, 33-52.

Rijlaarsdam, G., Van den Berg, H., \& Couzijn, M. (2005). Effective Learning and Teaching of Writing (2nd ed.). A Handbook of Writing in Education, New York, NY: Kluver Academic Publishers. https://doi.org/10.1007/978-1-4020-2739-0

Saint-Dizier de Almeida, V., \& Auriac-Slusarczyk, E. (2016). Les ateliers-philo en contexte scolaire. Recherche en Education, 24 Janvier 2016.

Slade, C. (2000). Pensée critique et créative. In R. Pallascio, \& L. Lafortune (Eds.), Pour une pensée réflexive en éducation (pp. 31-43). Sainte-Foy: Presses de l’Université du Québec.

Slusarczyk, B. et al. (2017). Philosoph'arts. Cartographie philosophique à l'usage des collégiens. Clermont-Ferrand: Eds Un, deux, quatre.

Slusarczyk, B., Fiema, G., Auriel, A., \& Auriac-Slusarczyk, E. (2015). Etude de l'impact d'une introduction de la philosophie dans les curriculums au primaire et au collège sur l'intégrité cognitive. Recherche \& Education, 14, 123-145.

Thebault, C. (2015). Une expérience d’atelier Philo \& Carto. Diotime, No. 65. http://www.educ-revues.fr/diotime/ListeSommaires.aspx?som=65

Topping, K. J., \& Trickey, S. (2007). Collaborative Philosophical Enquiry for School Children: Cognitive Effects at 10-12 Years. British Journal of Educational Psychology, 77, 271-288. https://doi.org/10.1348/000709906X105328

Tozzi, M. (2007). Apprendre à philosopher par la discussion. Brussels: De Boeck Université. 